\title{
Diagnóstico situacional del programa de malaria en la Comuna 5 de Tumaco 2019-2021. Resultados preliminares.
}

\section{Situational diagnosis of the malaria program in Commune 5 of Tumaco 2019-2021. Preliminary results.}

\author{
Mónica Marcela Jiménez $\mathrm{S}^{1}$, Pablo Enrique Chaparro N², María Luz Gunturiz A33, Julian Andrés Zamora D ${ }^{4}$, Pilar Pérez $\mathrm{C}^{5}$, Gabriel \\ Carrasquilla $\mathrm{G}^{6}$ y el grupo del Programa de control de ETV del Instituto Departamental de Salud de Nariño.
}

\section{RESUMEN}

Objetivo. Determinar prevalencia de malaria, características entomológicas y actividades del programa de prevención y control en área urbana de Tumaco (Comuna 5), entre 2019-2021. Materiales y métodos. Estudio descriptivo, financiado por Minciencias, basado en metodología cuali-cuantitativa. La cuantitativa empleó muestreo probabilístico, cuestionarios estructurados, diagnóstico por gota gruesa y prueba de diagnóstico rápido; identificó presencia de vectores mediante trampas y búsqueda activa; estimó prevalencia, frecuencias, porcentajes e índices entomológicos. La cualitativa utilizó muestreo no probabilístico, entrevistas semiestructuradas y análisis de contenido. Resultados. Participaron 1.504 individuos. Prevalencia por gota gruesa y prueba rápida de $0,73 \%$ y $0,53 \%$, respectivamente. Identificó Plasmodium falciparum; encontró 37 adultos en peridomicilio y 32 larvas en pozos y estanques de
Anopheles albimanus. Índice picadura-hombre-noche de 0,74, índice picadura-hombre-hora de 0,06, mayor actividad de picadura entre las 18:00-19:00 horas. Los actores refirieron demoras en atención, diagnóstico y tratamiento; difícil acceso al puesto de diagnóstico; problemas organizativos, falta de claridad de funciones en instituciones involucradas en el programa y desinterés de las comunidades por la prevención y el control. Conclusiones. La prevalencia fue baja, el vector se halló en el peridomicilio y criaderos artificiales, se requiere continuar mejorando diagnóstico y tratamiento para prevención y control de la malaria.

Palabras clave: malaria, prevalencia, Plasmodium falciparum, Anopheles albimanus, Tumaco.

Citación (Vancouver): Diagnóstico situacional del programa de malaria en la Comuna 5 de Tumaco 2019-2021. Resultados preliminares.. Rev Avances en Salud; 2021. (5) 1 :26-27 . doi: 10.21897/25394622.2520

\footnotetext{
${ }^{1}$ Bacterióloga, MSc en Salud Pública. Fundación Santa Fe de Bogotá monica.jimenez@fsfb.org.co

${ }^{2}$ Médico, Ph.D en Salud Pública. Instituto Nacional de Salud

${ }^{3}$ Bióloga, Ph.D en Biotecnología. Instituto Nacional de Salud

${ }^{4}$ Biólogo. Fundación Santa Fe de Bogotá

${ }^{5}$ Bacterióloga, Esp en Epidemiología. Instituto Departamental de Salud de Nariño

${ }^{6}$ Médico, Ph.D en Salud Pública. Fundación Santa Fe de Bogotá
} 


\begin{abstract}
Objective. To determine malaria prevalence, entomological characteristics, and activities of the prevention and control program in the urban area of Tumaco (Comuna 5), between 2019 and 2021. Materials and methods. Descriptive study, funded by Minciencias, based on qualitative-quantitative methodology. The quantitative methodology used probabilistic sampling, structured questionnaires, thick blood smear diagnosis, and rapid diagnostic test; we identified the presence of vectors through traps and active search; we estimated prevalence, frequencies, percentages, and entomological indices. The qualitative approach used non-probabilistic sampling, semi-structured interviews, and content analysis. Results. A total of 1,504 individuals participated. The prevalence by thick blood smear and rapid test of $0.73 \%$ and $0.53 \%$, respectively. We identified Plasmodium falciparum; we found 37 adults per domicile and 32 larvae in wells and ponds of Anopheles albimanus. The man-night biting index of 0.74 , man-hour biting index of 0.06 , greater biting activity between 18:00-19:00 hours. The stakeholders reported delays in care, diagnosis, and treatment; difficult access to the diagnostic; organizational problems, lack of clarity of functions in institutions involved in the program, and lack of interest of the communities in prevention and control. Conclusions. The prevalence was low, the vector was found in per domicile and artificial breeding sites, and it is necessary to continue improving diagnosis and treatment for malaria prevention and control.
\end{abstract}

Key words: malaria, prevalencia, Plasmodium falciparum, Anopheles albimanus, Tumaco.

\section{REFERENCIAS}

1. Organización Mundial de la Salud. Estrategia Técnica Mundial contra la Malaria 2016-2030. Disponible en: https://apps.who.int/iris/bitstream/ handle/10665/186671/9789243564999 spa.

2. Plan De Acción para la Eliminación de la Malaria. Organization Panamericana de la Salud 2014-2019. Disponible en: https:// www.paho.org/hq/dmdocuments/2016/ CD55-13-s.pdf?ua=1

3. Ministerio de Salud y Protección Social. Dirección de Promoción y Prevención. Subdirección de Enfermedades Transmisibles. Grupo Enfermedades Endemo-Epidémicas. Plan Estratégico Nacional de Malaria 2019- 2022. Disponible en: https://www.minsalud.gov. $\mathrm{co/sites/rid/Lists/BibliotecaDigital/RIDE/}$ VS/PP/PAl/plan-estrategico-malaria.pdf 